\title{
The raccoon dog (Nyctereutes procyonoides) and the raccoon (Procyon lotor) - their role and impact of maintaining and transmitting zoonotic diseases in Austria, Central Europe
}

\author{
Tanja Duscher ${ }^{1}$ • Adnan Hodžić ${ }^{2}$ - Walter Glawischnig ${ }^{3}$ - Georg G. Duscher ${ }^{2}$
}

Received: 21 December 2016 / Accepted: 3 February 2017 / Published online: 23 February 2017

(C) The Author(s) 2017. This article is published with open access at Springerlink.com

\begin{abstract}
The neozoan species raccoon dog (Nyctereutes procyonoides) and raccoon (Procyon lotor) are widespread in Europe and potential vectors of many diseases that can threaten human and domestic animal health. Facing a further spread of these species, it is important to know about (i) pathogens imported and/or (ii) pathogens acquired in the new habitat. Thus, we investigated the parasite fauna of wild raccoon dogs and raccoons from Austria, at the edge of their new distribution range. The eight examined raccoons were nearly free of pathogens including Baylisascaris procyonis, and thus assumed to have a low epidemiological impact, so far. Out of ten raccoon dog specimens, we found one from western Austria to be infected with Echinococcus multilocularis and another three from the eastern wetland regions to harbour adults of Alaria alata. Furthermore, we detected Babesia cf. microti in five of eight raccoon dogs all over Austria but none of our samples were tested positive for Trichinella spp. Nevertheless, the raccoon dog seems to be a relevant host, at least for the zoonotic pathogens E. multilocularis and A. alata, and we suggest to further monitor the raccoon dogs parasite fauna.
\end{abstract}

Georg G. Duscher

georg.duscher@vetmeduni.ac.at

1 Research Institute of Wildlife Ecology, Department of Integrative Biology and Evolution, University of Veterinary Medicine Vienna, Vienna, Austria

2 Institute of Parasitology, Department of Pathobiology, University of Veterinary Medicine Vienna, Veterinaerplatz 1,

A-1210 Vienna, Austria

3 Institute for Veterinary Disease Control, Austrian Agency for Health and Food Safety, Innsbruck, Austria
Keywords Alaria alata Echinococcus multilocularis . Babesia cf. microti · Trichinella spp. · Baylisascaris procyonis $\cdot$ Neozoa

\section{Introduction}

Two of the most widespread non-indigenous wildlife species in Europe are the raccoon dog (Nyctereutes procyonoides) and the raccoon (Procyon lotor). Both species have been introduced to Europe in the twentieth century but their origin is completely the opposite, namely the USA for the raccoon and the Far East for the raccoon dog (Lutz 1984; Nowak 1973; Stubbe 1975). In the former decades, these new carnivore species expanded their range, increased in abundance, and even became the most common carnivore species in some parts of Europe (Kowalczyk 2014; Laurimaa et al. 2015). Consequently, there is a need to spend attention to these neozoa as additional wildlife reservoir of zoonotic diseases in Europe.

The most serious problem concerning the raccoon dog invasion seems to be the transmission of zoonotic diseases (Kauhala and Kowalczyk 2011). In Europe, the raccoon dog can be infected with a minimum of 32 helminth species of which 19 are zoonotic (Laurimaa et al. 2016). Its parasite fauna is similar to that of the indigenous red fox (Vulpes vulpes) (Al-Sabi et al. 2013; Bružinskaitè-Schmidhalter et al. 2012; Laurimaa et al. 2015; Thiess et al. 2001). The raccoon dog is assumed to be an important additional host species of Echinococcus multilocularis (Kauhala and Kowalczyk 2011; Schwarz et al. 2011; Tackmann et al. 2003) and moreover is highly susceptible for Alaria alata (Al-Sabi et al. 2013; Bružinskaitė-Schmidhalter et al. 2012; Laurimaa et al. 2016). The raccoon dog is also known to be an important reservoir host of Trichinella spp. (Bružinskaitè-Schmidhalter 
et al. 2012; Kauhala and Kowalczyk 2011; Thiess et al. 2001) and has been identified as important rabies vector in northeastern Europe (Holmala and Kauhala 2006; Singer et al. 2009). Due to broad oral vaccination campaigns, rabies is of less relevance in central Europe and is known to be eradicated in Austria since 2008 (Hirk et al. 2014). However, spill-over from neighbouring countries may still occur (Duscher et al. 2015). As the raccoon dog population is still growing and spreading, its role as a vector of this dangerous virus as well as of other zoonotic diseases may further increase in Europe (Kauhala and Kowalczyk 2011; Sutor et al. 2014).

While the raccoon is known to be the host of many helminth parasite species in its native range (e.g. Harkema and Miller 1964), previous studies from Germany, the country with the highest raccoon density in Europe, showed a remarkably low endoparasitic burden (e.g. Schwarz et al. 2015). The most prevalent parasites of raccoons found in recent studies were Mesocestoides spp. (Karamon et al. 2014; Schwarz et al. 2015). But the most serious zoonotic disease transmitted by raccoons in Europe seems to be the Larva migrans syndrome caused by Baylisascaris procyonis. The estimated prevalence of this parasite in European raccoon populations showed high geographical variations, ranging from 0 up to $71 \%$ (Al-Sabi et al. 2016; Gey 1998; Karamon et al. 2014; Schwarz et al. 2015; Winter et al. 2005). Concerning rabies, the raccoon is not considered to be a reservoir host in Europe, probably because of a low susceptibility for the relevant rabies virus variants (Vos et al. 2012). Among the piroplasmids, Babesia $\mathrm{cf}$. microti was found in raccoons and raccoon dogs so far (Alvarado-Rybak et al. 2016; Han et al. 2010). This pathogen is frequently confirmed in foxes in Austria (Duscher et al. 2014), as well as in other regions of Europe sometimes infecting dogs (Camacho et al. 2004). This group comprises different clades and is also known as Babesia microti-like, Babesia annae, Babesia "Spanish dog isolate", Theileria annae and Babesia vulpes (Baneth et al. 2015), but due to the lack of a valid description, it only can be informally named as the "microti group" (Harris 2016). Additionally, it has been stated that raccoons might get infected with at least three different Babesia species (Alvarado-Rybak et al. 2016).

The distribution and transmission of parasites depend on several environmental factors and thus differ across geographical regions (Dybing et al. 2013; Mackenstedt et al. 2015; Monello and Gompper 2011). So far, all studies concerning the parasite fauna of the raccoon dog as well as of the raccoon in Europe were conducted in the northeastern countries of its introduced range. Facing a range expansion of these neozoan species towards South Europe (Kauhala and Winter 2006; Winter 2006), further studies are needed to understand their role and impact of maintaining and transmitting zoonotic diseases in Europe's diverse landscapes and climatic regions. Thus, we investigated the parasite fauna of wild raccoon dogs and raccoons from Austria, on the edge of both species' geographic ranges. So far, the population densities in Austria do not reach high numbers but hunting bags are increasing (Duscher 2016). Therefore, sampling of statistical sufficient numbers to calculate parameters hardly seems possible. Nevertheless, any data of those species in the newly spread area is of great interest. It may give hints about (i) pathogens imported and/or (ii) pathogens acquired in the new habitat.

\section{Material and methods}

Raccoons and raccoon dogs were obtained via regular hunting and catching events between February 2010 and January 2016 all over Austria under the restrictions of the Austrian game laws. Samples of in total eight raccoons and 13 raccoon dogs were obtained. Due to the small number of samples collected over 6 years, this is neither a longitudinal nor a cross-sectional study design. In some cases, only parts (e.g. intestines or tissue samples) were provided by the hunters. Either the whole animal or the intestines only, which were excised under high safety standards, were frozen at $-80{ }^{\circ} \mathrm{C}$ for a minimum of 14 days to inactivate E. multilocularis oncosphaera. The intestines of seven raccoons and ten raccoon dogs were analysed by using the "shaking in a vessel" technique which was previously described (Duscher et al. 2005) (Table 1). Muscle tissues, at least $5 \mathrm{~g}$ if available (diaphragm or limb muscle), were analysed for Trichinella spp. by artificial digestion method at the National Reference Laboratory (Institute for Veterinary Disease Control, Austrian Agency for Health and Food Safety, Innsbruck, Austria). Spleens of four raccoons and eight raccoon dogs were analysed for piroplasmids (Babesia/Theileria spp.) and Anaplasmataceae (Anaplasma spp./Ehrlichia canis and Candidatus Neoehrlichia spp.) by using a nested and a single PCR, respectively, according to a protocol previously published (Duscher et al. 2013; Hodžić et al. 2015).

\section{Results}

Concerning the human relevant parasites, we detected A. alata in the intestines of three raccoon dogs $(30 \%)$ as well as $E$. multilocularis in one raccoon dog intestine (10\%) (Table 2). The examined raccoon dogs were also infected with Uncinaria stenocephala (40\%), Mesocestoides spp. (40\%), Molineus spp. (30\%), Toxocara canis (20\%), Taenia spp. (20\%), Isthmiophora melis (20\%), Dipylidium caninum $(10 \%)$ and Toxascaris leonina (10\%). Seven examined raccoons were free of gastrointestinal parasites, and one specimen was infected with Molineus spp.

The results of the PCR showed no Anaplasmataceae infections of the four raccoons as well as of the eight raccoon dogs examined. However, none of the raccoons but five of eight 
Table 1 Numbers of raccoons and raccoon dogs with the available material and the method used for analysis

\begin{tabular}{|c|c|c|c|c|c|}
\hline \multirow[t]{2}{*}{ Species/no. } & \multicolumn{3}{|c|}{ Material available/method used } & \multirow[t]{2}{*}{ Collection year } & \multirow[t]{2}{*}{ Province } \\
\hline & Intestines & Muscle & Spleen & & \\
\hline Raccoon 189 & SVT & n.a. & n.a. & 2010 & Salzburg \\
\hline Raccoon 229 & SVT & n.a. & n.a. & 2010 & Lower Austria \\
\hline Raccoon 251 & SVT & n.a. & n.a. & 2011 & Styria \\
\hline Raccoon 253 & SVT & n.a. & n.a. & 2010 & Styria \\
\hline Raccoon 311 & n.a. & n.a. & PCR & 2013 & Lower Austria \\
\hline Raccoon 328 & SVT & n.a. & PCR & 2015 & Carinthia \\
\hline Raccoon 400 & SVT & Diaphragm $(<5 \mathrm{~g})$ & PCR & 2015 & Lower Austria \\
\hline Raccoon 401 & SVT & Diaphragm & PCR & 2016 & Lower Austria \\
\hline Raccoon dog 211 & SVT & n.a. & n.a. & 2010 & Burgenland \\
\hline Raccoon dog 247 & SVT & n.a. & n.a. & 2011 & Burgenland \\
\hline Raccoon dog 255 & SVT & Limb & n.a. & 2011 & Burgenland \\
\hline Raccoon dog 256 & SVT & $\operatorname{Limb}(<5 \mathrm{~g})$ & n.a. & 2011 & Lower Austria \\
\hline Raccoon dog 266 & SVT & Limb & n.a. & 2011 & Lower Austria \\
\hline Raccoon dog 293 & SVT & n.a. & PCR & 2012 & Burgenland \\
\hline Raccoon dog 314 & SVT & n.a. & PCR & 2014 & Vorarlberg \\
\hline Raccoon dog 321 & n.a. & n.a. & PCR & 2014 & Lower Austria \\
\hline Raccoon dog 322 & n.a. & n.a. & PCR & 2014 & Lower Austria \\
\hline Raccoon dog 324 & n.a. & n.a. & PCR & 2014 & Lower Austria \\
\hline Raccoon dog 389 & SVT & Diaphragm & PCR & 2015 & Lower Austria \\
\hline Raccoon dog 394 & SVT & Diaphragm & PCR & 2015 & Styria \\
\hline Raccoon dog 397 & SVT & Limb/Diaphragm & PCR & 2015 & Lower Austria \\
\hline
\end{tabular}

$P C R$ polymerase chain reaction used for piroplasmids and Anaplasmatacae, SVT shaking in a vessel technique, n.a. not available

Table 2 Parasite species detected in the examined raccoon (left) and raccoon dog (right) specimens and infestation intensity (middle intense for Echinococcus multilocularis: 101-1000 specimens, low intense for Mesocestoides sp.: below 30 specimens)

\begin{tabular}{|c|c|c|c|c|c|c|c|c|c|c|c|c|c|c|c|c|c|c|c|c|c|}
\hline \multirow{2}{*}{$\begin{aligned} & \text { Species } \\
& \text { ID }\end{aligned}$} & \multicolumn{8}{|c|}{ Raccoon } & \multicolumn{13}{|c|}{ Raccoon dog } \\
\hline & 189 & 229 & 251 & 253 & 311 & 328 & 400 & 401 & 211 & 247 & 255 & 256 & 266 & 293 & 314 & 321 & 322 & 324 & 389 & 394 & 397 \\
\hline Alaria alata & 0 & 0 & 0 & 0 & - & 0 & 0 & 0 & 6 & 0 & 23 & 0 & 37 & 0 & 0 & - & - & - & 0 & 0 & 0 \\
\hline Isthmiophora melis & 0 & 0 & 0 & 0 & - & 0 & 0 & 0 & 0 & 0 & 9 & 1 & 0 & 0 & 0 & - & - & - & 0 & 0 & 0 \\
\hline $\begin{array}{r}\text { Dipylidium } \\
\text { caninum }\end{array}$ & 0 & 0 & 0 & 0 & - & 0 & 0 & 0 & 0 & 0 & 0 & 0 & 0 & 0 & 0 & - & - & - & 0 & 0 & 1 \\
\hline $\begin{array}{l}\text { Echinococcus } \\
\quad \text { multilocularis }\end{array}$ & 0 & 0 & 0 & 0 & - & 0 & 0 & 0 & 0 & 0 & 0 & 0 & 0 & 0 & $\begin{array}{l}\text { Middle } \\
\text { intense }\end{array}$ & - & - & - & 0 & 0 & 0 \\
\hline Mesocestoides sp. & 0 & 0 & 0 & 0 & - & 0 & 0 & 0 & 0 & 1 & 1 & 0 & 0 & $\begin{array}{l}\text { Low } \\
\text { in- } \\
\text { tense }\end{array}$ & 5 & - & - & - & 0 & 0 & 0 \\
\hline Taenia sp. & 0 & 0 & 0 & 0 & - & 0 & 0 & 0 & 0 & 0 & 0 & 0 & 0 & 0 & 0 & - & - & - & 1 & 0 & 3 \\
\hline Molineus sp. & 1 & 0 & 0 & 0 & - & 0 & 0 & 0 & 1 & 12 & 1 & 0 & 0 & 0 & 0 & - & - & - & 0 & 0 & 0 \\
\hline Toxascaris leonina & 0 & 0 & 0 & 0 & - & 0 & 0 & 0 & 0 & 0 & 0 & 1 & 0 & 0 & 0 & - & - & - & 0 & 0 & 0 \\
\hline Toxocara canis & 0 & 0 & 0 & 0 & - & 0 & 0 & 0 & 0 & 0 & 0 & 1 & 0 & 0 & 0 & - & - & - & 0 & 0 & 5 \\
\hline Trichinella sp. & - & - & - & - & - & - & $0^{\mathrm{a}}$ & 0 & - & - & 0 & $0^{\mathrm{a}}$ & 0 & - & - & - & - & - & 0 & 0 & 0 \\
\hline $\begin{array}{l}\text { Uncinaria } \\
\text { stenocephala }\end{array}$ & & & & & & & & & & & & & & & & & & & & & \\
\hline Babesia cf. microti & - & - & - & - & 0 & 0 & 0 & 0 & - & - & - & - & - & 1 & 1 & 0 & 1 & 0 & 1 & 0 & 1 \\
\hline Anaplasmatacae sp. & - & - & - & - & 0 & 0 & 0 & 0 & - & - & - & - & - & 0 & 0 & 0 & 0 & 0 & 0 & 0 & 0 \\
\hline
\end{tabular}

${ }^{\mathrm{a}}$ Less than $5 \mathrm{~g}$ of muscle available 


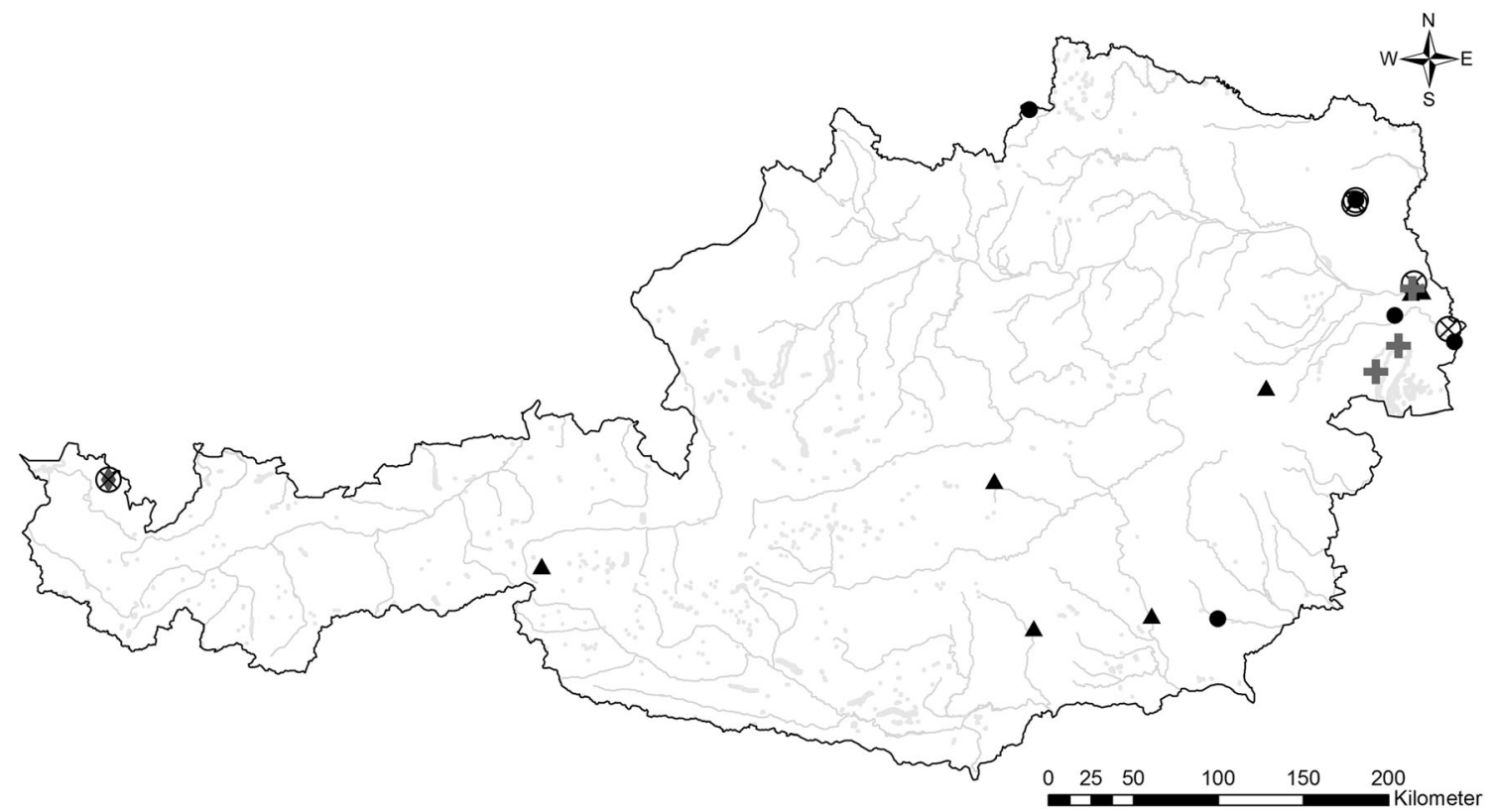

Fig. 1 Geographical distribution of raccoon dogs infected with Alaria alata (廿),Babesia cf. microti $(\bigotimes)$ and Echinococcus multilocularis $(\$)$ as well as of raccoons $(\boldsymbol{\Delta})$ and raccoon dogs $(\bullet)$ not infected with the relevant parasites (see above)

raccoon dogs were tested positive for $B$. cf. microti (Genbank ${ }^{\circledR}$ accession number [KY246306]). The sequence (partial 18S rRNA) were $100 \%$ identical to each other and to the sequences found in foxes from Austria (e.g. [KM115972]). The Trichinella analysis showed all of the investigated raccoon and raccoon dog samples were free of Trichinella spp.although, two of the samples consisted of less than $5 \mathrm{~g}$ and thus were probably not representative.

The A. alata infected raccoon dogs originated from eastern Austria, precisely from the Lake Neusiedl and the Danube floodplain areas (Fig. 1), while the E. multilocularis positive raccoon dog was shot in the northwestern edge of the country. Tissues of the racoon dogs infested with $B$. cf. microti were sampled in the east as well as in the west.

\section{Discussion}

Interestingly, the E. multilocularis appeared in the western areas of Austria, those areas of known high endemicity of this cestode in foxes (Duscher et al. 2006). The host competence of the raccoon dog for E. multilocularis is in accordance with studies from other countries (e.g. Al-Sabi et al. 2013; Laurimaa et al. 2015; Schwarz et al. 2011; Thiess et al. 2001). But, due to its feeding habits, the raccoon dog seems to play a minor role as a reservoir of E. multilocularis than the red fox does (Al-Sabi et al. 2013; Bružinskaitè-Schmidhalter et al. 2012).

In contrast, the trematode A. alata was found in the eastern parts surrounding the Lake Neusiedl, and in the Danube floodplains where this parasite was also found in foxes (Duscher 2011), and where the densities of paratenic hosts are high.
These wetlands are also the areas with a high probability of raccoon dog presence (Duscher and Nopp-Mayr under review), and where future population densities are expected to be high. Our results confirm previous European studies that showed a high abundance of $A$. alata in raccoon dogs and thus a probable high susceptibility of the raccoon dog for this gastrointestinal parasite with high zoonotic relevance (Al-Sabi et al. 2013).

Furthermore, B. cf. microti was found in five out of eight investigated raccoon dogs. To our knowledge, this is the first evidence of a $B$. cf. microti infection of raccoon dogs in Europe and is in accordance with the idea of sharing the fox parasites, as seen for the gastrointestinal parasites. In this context, the raccoon dog may be seen as additional reservoir of $B$. cf. microti as already suggested by Han et al. (2010). Contrary to that, the raccoons were negative for this pathogen, although the $B$. cf. microti species found in Austrian foxes is closely related to those found in raccoons in Japan (Baneth et al. 2015). So, in this case, the same type of pathogen also could circulate among the host species. Unfortunately, the sample size is too low to either confirm or reject this assumption.

No Anaplasmataceae were found, which might have occurred in the raccoons, e.g. the raccoon-associated bacteria Candidatus Neoehrlichia lotoris (CNL) as stated in previous works (Hodžić et al. 2015, 2016). These bacteria were found and described in raccoons from the USA (Yabsley et al. 2008), but recently were accidentally found in foxes from Austria and the Czech Republic (Hodžić et al. 2015, 2016), far away from the US distribution. Likewise, all examined raccoon and raccoon dog samples were free of Trichinella spp., but due to the small sample size, no clear declaration can be made. 
Generally, our examined raccoons were almost pathogen free, which also was observed in other studies within their introduced range (e.g. Schwarz et al. 2015). The idea is that in some regions, introduced raccoons were originating from fur farms and dewormed in regular manner. Thus, geographical differences in the worm prevalence, e.g. B. procyonis, within their introduced range are supposed to depend on the source population (Schwarz et al. 2015; Winter et al. 2005). In opposite to the raccoon dog, the raccoon is not that suitable for fox parasites (Schwarz et al. 2015; Thiess et al. 2001). This might be the explanation for the overall lower prevalence in the investigated raccoons in this study.

\section{Conclusion}

Due to the low population densities of the raccoon and the raccoon dog in Austria (Duscher 2016), our sample size is quite low and varying. Nevertheless, our results support the thesis of Michler and Michler (2012) that the epidemiological meaning of the raccoon in Europe is still low. However, a further spread and population increase of this non-indigenous species will obviously lead to an admixture of the different founder populations (Biedrzycka et al. 2014; Fischer et al. 2015), and therewith to a further spread of $B$. procyonoides as well. In the case of the raccoon dog, our results confirm it as a host of E. multilocularis as well as a probable indicator species of A. alata. As the origins of $A$. alata positive samples are also the regions with expected high raccoon dog population densities (Duscher and Nopp-Mayr under review), A. alata infections is an increasing risk. Moreover, our study confirms the raccoon dog as an additional host of $B$. cf. microti with a relevant impact as a reservoir. Concerning its epidemiological impact and facing a further spread in Europe, the raccoon dog should be monitored more intensively in the matters of vector-borne diseases (Sutor et al. 2014).

Acknowledgement Open access funding is provided by the University of Veterinary Medicine Vienna, Austria. We thank all hunters, preparators and museums staff who provided specimen, gastrointestinal tracts and/or tissue sample for our examination. Furthermore, we thank the team of the pathology lab at the Research Institute of Wildlife Ecology for their help.

\section{Compliance with ethical standards}

Conflict of interest The authors declare that they have no conflict of interest.

Ethical approval All applicable international, national and/or institutional guidelines for the care and use of animals were followed.

Open Access This article is distributed under the terms of the Creative Commons Attribution 4.0 International License (http:// creativecommons.org/licenses/by/4.0/), which permits unrestricted use, distribution, and reproduction in any medium, provided you give appropriate credit to the original author(s) and the source, provide a link to the Creative Commons license, and indicate if changes were made.

\section{References}

Al-Sabi MNS, Chriél M, Jensen TH, Enemark HL (2013) Endoparasites of the raccoon dog (Nyctereutes procyonoides) and the red fox (Vulpes vulpes) in Denmark 2009-2012 - a comparative study. In J Parasitol: Parasite Wildlife 2:144-151. doi:10.1016/j.ijppaw.2013. 04.001

Al-Sabi MNS, Chriél M, Hansen MS, Enemark HL (2016) Baylisascaris procyonis in wild raccoons (Procyon lotor) in Denmark. Veterinary Parasitology: Regional Studies and Reports 1-2:55-58. doi:10.1016/ j.vprsr.2016.03.001

Alvarado-Rybak M, Solano-Gallego L, Millan J (2016) A review of piroplasmid infections in wild carnivores worldwide: importance for domestic animal health and wildlife conservation. Parasit Vectors 9:538. doi:10.1186/s13071-016-1808-7

Baneth G, Florin-Christensen M, Cardoso L, Schnittger L (2015) Reclassification of Theileria annae as Babesia vulpes sp. nov. Parasit Vectors 8:207. doi:10.1186/s13071-015-0830-5

Biedrzycka A, Zalewski A, Bartoszewicz M, Okarma H, Jędrzejewska E (2014) The genetic structure of raccoon introduced in Central Europe reflects multiple invasion pathways. Biol Invasions 16: 1611-1625. doi:10.1007/s10530-013-0595-8

Bružinskaitė-Schmidhalter R, Šarkūnas M, Malakauskas A, Mathis A, Torgerson PR, Deplazes P (2012) Helminths of red foxes (Vulpes vulpes) and raccoon dogs (Nyctereutes procyonoides) in Lithuania. Parasitology 139:120-127. doi:10.1071/S0031182011001715

Camacho AT et al (2004) Azotemia and mortality among Babesia microti-like infected dogs. J Vet Intern Med 18:141-146

Duscher GG (2011) Der Dunckersche Muskelegel—Alaria alata beim Rotfuchs in Österreich in Relation zum Vorkommen von Wildschweinen. Wiener Tierärztliche Monatsschrift 98:251-254

Duscher T (2016) The current status of the raccoon (Procyon lotor) and the raccoon dog (Nyctereutes procyonoides) in Austria. Beitr Jagd Wildforsch 41:285-293

Duscher T, Nopp-Mayr U (under review) Species distribution modelling for the invasive raccoon dog (Nyctereutes procyonoides) in Austria and first range predictions for alpine environments. Arch Biol Sci

Duscher GG, Prosl H, Joachim A (2005) Scraping or shaking - a comparison of methods for the quantitative determination of Echinococcus multilocularis in fox intestines. Parasitol Res 95:4042. doi:10.1007/s00436-004-1260-z

Duscher GG, Pleydell D, Prosl H, Joachim A (2006) Echinococcus multilocularis in Austrian foxes from 1991 until 2004. J Vet Med B Infect Dis Vet Public Health 53:138-144. doi:10.1111/j.14390450.2006.00930.x

Duscher GG, Kubber-Heiss A, Richter B, Suchentrunk F (2013) A golden jackal (Canis aureus) from Austria bearing Hepatozoon canisimport due to immigration into a non-endemic area? Ticks and tickborne diseases 4:133-137. doi:10.1016/j.ttbdis.2012.10.040

Duscher GG, Fuehrer H-P, Kübber-Heiss A (2014) Fox on the runmolecular surveillance of fox blood and tissue for the occurrence of tick-borne pathogens in Austria. Parasite Vectors 7:521. doi:10. 1186/s13071-014-0521-7

Duscher GG, Leschnik M, Fuehrer HP, Joachim A (2015) Wildlife reservoirs for vector-borne canine, feline and zoonotic infections in Austria. Int J Parasitol: Parasite Wildlife 4:88-96. doi:10.1016/j. ijppaw.2014.12.001

Dybing NA, Fleming PA, Adams PJ (2013) Environmental conditions predict helminth prevalence in red foxes in Western Australia. Int $\mathrm{J}$ Parasitol: Parasite Wildlife 2:165-172. doi:10.1016/j.ijppaw.2013. 04.004

Fischer ML et al (2015) Historical invasion records can be misleading: genetic evidence for multiple introductions of invasive raccoons (Procyon lotor) in Germany. PLoS One 10:e0125441. doi:10. 1371/journal.pone.0125441 
Gey AB (1998) Synopsis der Parasitenfauna des Waschbären (Procyon lotor) unter Berücksichtigung von Befunden aus Hessen. Dissertation, Justus Liebig-Universität Gießen

Han J-I, Lee S-J, Jang H-J, Na K-J (2010) Asymptomatic Babesia microti-like parasite infection in wild raccoon dogs (Nyctereutes procyonoides) in South Korea. J Wildl Diseases 46:632-635

Harkema R, Miller GC (1964) Helminth parasites of the raccoon, Procyon lotor in the southeastern United States. J Parasitol 50:60-66

Harris DJ (2016) Naming no names: comments on the taxonomy of small piroplasmids in canids. Parasit Vectors 9:289. doi:10.1186/s13071016-1567-5

Hirk S, Allerberger F, Huhulescu S, Indra A, Kallab V, Lachner P, Schmid D, Wewalka G (2014) Tollwut. Bundesministerium für Gesundheit and AGES - Österreichische Agentur für Gesundheit und Ernährungssicherheit GmbH, Wien

Hodžić A, Cézanne R, Duscher GG, Harl J, Glawischnig W, Fuehrer H-P (2015) Candidatus Neoehrlichia sp. in an Austrian fox is distinct from Candidatus Neoehrlichia mikurensis, but closer related to Candidatus Neoehrlichia lotoris. Parasit Vectors 8:539. doi:10. 1186/s13071-015-1163-0

Hodžić A, Mitkovà B, Modrý D, Juránková J, Frgelecová L, Forejtek P, Steinbauer V, Duscher GG (2016) A new case of the enigmatic Candidatus Neoehrlichia sp. (FU98) in a fox from the Czech Republic. Mol Cell Probe. doi:10.1016/j.mcp.2016.02.005

Holmala K, Kauhala K (2006) Ecology of wildlife rabies in Europe. Mammal Rev 36:17-36

Karamon J, Kochanowski M, Cencek T, Bartoszewicz M, Kusyk P (2014) Gastrointestinal helminths of raccoons (Procyon lotor) in western Poland (Lubuskie province) - with particular regard to Baylisascaris procyonis. Bull Vet Inst Pulawy 58:547-552. doi:10. 2478/bvip-2014-0084

Kauhala K, Kowalczyk R (2011) Invasion of the raccoon dog Nyctereutes procyonoides in Europe: history of colonization, features behind its success, and threats to native fauna. Curr Zool 57:584-598

Kauhala K, Winter M (2006) Nyctereutes procyonoides. Species factsheet. DAISIE - Delivering Alien Invasive Species Inventories for Europe. http://www.europe-aliens.org/pdf/Nyctereutes procyonoides.pdf. Accessed 15 Nov 2016

Kowalczyk R (2014) Nyctereutes procyonoides. NOBANIS - Invasive Alien Species Fact Sheet. https://www.nobanis.org/globalassets/ speciesinfo/n/nyctereutes-procyonoides/nyctereutes procyonoidesfinal.pdf. Accessed 05 Feb 2016

Laurimaa L, Suld K, Moks E, Valdmann H, Umhang G, Knapp J, Saarma U (2015) First report of the zoonotic tapeworm Echinococcus multilocularis in raccoon dogs in Estonia, and comparisons with other countries in Europe. Vet Parasitol 212:200-205. doi:10.1016/ j.vetpar.2015.06.004

Laurimaa L, Suld K, Davison J, Moks E, Valdmann H, Saarma U (2016) Alien species and their zoonotic parasites in native and introduced ranges: the raccoon dog example. Vet Parasitol 219:24-33. doi:10. 1016/j.vetpar.2016.01.020

Lutz W (1984) Die Verbreitung des Waschbären (Procyon lotor, Linné 1758) im mitteleuropäischen Raum. Z Jagdwiss 30:218-228
Mackenstedt U, Jenkins D, Romig T (2015) The role of wildlife in the transmission of parasitic zoonoses in peri-urban and urban areas international. J Parasitol: Parasite Wildlife 4:71-79. doi:10.1016/j. ijppaw.2015.01.006

Michler F, Michler B (2012) Ökologische, ökonomische und epidemiologische Bedeutung des Waschbären (Procyon lotor) in Deutschland-eine aktuelle Übersicht. Beitr Jagd Wildforsch 37: 389-397

Monello RJ, Gompper ME (2011) Effects of resource availability and social aggregation on the species richness of raccoon endoparasite infracommunities. Oikos 120:1427-1433

Nowak E (1973) Ansiedlung und Ausbreitung des Marderhundes (Nyctereutes procyonoides GRAY) in Europa. Beitr Jagd Wildforsch 8:351-383

Schwarz S, Sutor A, Staubach C, Mattis R, Tackmann K, Conraths FJ (2011) Estimated prevalence of Echinococcus multilocularis in raccoon dogs Nyctereutes procyonoides in northern Brandenburg, Germany. Curr Zool 57:655-661

Schwarz S, Sutor A, Mattis R, Conraths FJ (2015) Der Waschbärspulwurm (Baylisascaris procyonis)-kein Zoonoserisiko für Brandenburg? Berl Munch Tierarztl Wochenschr 128:34-38

Singer A, Kauhala K, Holmala K, Smith GC (2009) Rabies in northeastern Europe - the threat from invasive raccoon dogs. J Wildl Diseases 45:1121-1137

Stubbe M (1975) Der Waschbär Procyon lotor (L., 1758) in der DDR. Hercynia 12:80-91

Sutor A, Schwarz S, Conraths FJ (2014) The biological potential of the raccoon dog (Nyctereutes procyonoides, Gray 1834) as an invasive species in Europe-new risks for disease spread? Acta Theriol 59:4959. doi:10.1007/s13364-013-0138-9

Tackmann K, Goretzki J, Conraths FJ (2003) Das Neozoon Marderhund als neue Endwirtpopulation für Echinococcus multilocularis in Ostdeutschland - ein Risiko? Angewandte Wissenschaft Schriftreihe des BMVEL 498:176-181

Thiess A, Schuster R, Nöckler K, Mix H (2001) Helminthenfunde beim einheimischen Marderhund Nyctereutes procyonoides (Gray, 1834). Berl Munch Tierarztl Wochenschr 114:273-276

Vos A, Ortmann S, Kretzschmar AS, Köhnemann B, Michler F (2012) The raccoon (Procyon lotor) as potential rabies reservoir species in Germany: a risk assessment. Berl Munch Tierarztl Wochenschr 125: $228-235$

Winter M (2006) Procyon lotor. Species factsheet. DAISIE - Delivering Alien Invasive Species Inventories for Europe. http://www.europealiens.org/pdf/Procyon_lotor.pdf. Accessed 15 Nov 2016

Winter M, Stubbe M, Heidecke D (2005) Zur Ökologie des Waschbären (Procyon lotor L., 1758) in Sachsen-Anhalt. Beitr Jagd Wildforsch 30:303-322

Yabsley MJ, Murphy SM, Luttrell MP et al (2008) Characterization of "Candidatus Neoehrlichia lotoris" (family Anaplasmataceae) from raccoons (Procyon lotor). Int J Syst Evol Microbiol 58:2794-2798. doi:10.1016/j.biotechadv.2011.08.021 